\title{
Farm Machinery and Power Availability for Mechanizing Small-Scale Rice Farming Cultivations in Kampar Region, Indonesia
}

\author{
Ujang Paman* \\ Department of Agribusiness, Riau Islamic University, Indonesia
}

*Corresponding author: Department of Agribusiness, Riau Islamic University, Indonesia

\begin{abstract}
Farm machinery is one of important power sources for performing various farm operations today. The availability of adequate farm machinery is essential for providing sufficient power on the farm. Thus, the various farm operations can be well-mechanized and can contribute to the overall improved productivity of crops. This study attempted to examine the farm machinery and power availability for mechanizing small-scale rice farming operations in Kampar Region, Indonesia. Data were collected through field survey in the selected rice production centers in the region. The interviews with involving farmers, government extension staff and machinery suppliers were conducted in 2015. The results showed that small type of farm machinery is mostly demanded by farmers, including power tillers, water pumps, power threshers, and rice milling units (RMUs). The machines are suitable to farm conditions that are small in size and purchasing power of farmers. However, the number of farm machinery available was not sufficient to provide power requirements for mechanizing overall rice farm operations. Public financial support and private sector involvement are strongly needed to promote farm machinery use among small scale farmers.
\end{abstract}

Keywords: Farm machinery demand; Power requirement; Small rice farm; Kampar region

\section{Introduction}

Agriculture has undergone modernization across the world. Agricultural mechanization is an important element for modernization of the agriculture [1] and plays a key role in improving agricultural production in developing countries [2]. Farm mechanization implies the use of mechanical technology in the varied farming operations [3] and then takes the place of human and animal power in agricultural processes. Essentially, agricultural mechanization represents technological change through the adoption of nonhuman sources of power to undertake agricultural operations [4]. Energy (power) is one of the most valuable inputs in production agriculture [5]. The technical change from human and/or animal power to machine power in agriculture will tend to increase machinery demand of farmers. Power and machinery are an integral part of modern agriculture, so the development of the machines used in the modern agriculture has also brought new demands on farmers [6].

The mechanization of farming, particularly in developing countries, has been very uneven [7]. In Indonesia, agricultural mechanization is currently still in the developing stage and its development speed remains slow and differs across the country. Slow development process in the country may be caused by some constraints, including socioeconomic, technical, and institutional constraints [8]. Consequently, the level of mechanization in the country was relatively low with an average level of 30\% [9]. In Riau Province, Paman, et al. [10] reported that the mechanization degree was only about $28 \%$ in 2013 . The low mechanization level in the province may be caused by shortage number and application of farm machines by farmers. During a period of 2009-2013, the number of major farm machines in the province, including tractors, water pumps, power threshers and rice milling units, increased from 5,610 units to 6,371 units or increased at about $6 \%$ annually [11].

According to Handaka [9], the mechanization development in Indonesia would follow and highly depended upon the process of national economic development. Government support has also significantly contributed to the advancement of farm machinery 
use among farmers through primarily financing for farm machinery purchase. It means that the improvement of farmers' economic condition as a result of economic growth will tend to increase demand of farm machinery that has highly powerful and efficiency. Farm machinery is also required to fulfill an energy requirement for performing various farm operations. A worldwide study has concluded that for optimum yields, there is a need for a power input at least $0.8 \mathrm{hp}$. ha- ${ }^{-1}$ [12]. In addition, demand for mechanization depends on some factors, such as farming system intensity, the availability of complementary technologies, and the capacity to fully use machines [4] Sufficient availability of the right energy (power) and its effective and efficient use are prerequisites for improved agricultural production [13]. This study attempted to examine the farm machinery and power availability for small-scale rice farming operations in Kampar Region, Indonesia. This is important to meet the needs of farmers of farm machinery as a source of power for effective and efficient farm operations.

\section{Materials and Methods}

This study was carried out in Kampar, one of the 12 regions in Riau Province, Indonesia. The region consists of 21 districts and 250 villages with total area of $11.289,28 \mathrm{sq}-\mathrm{km}$. Total population is 371.449 with a density of $30 \mathrm{sq}-\mathrm{km}^{-1}$. Kampar region is the most important area because it is one of the major rice production area in the province. Farm machines have been used in the area for many years and tend to increase from year to year.

This study was carried out in 15 selected districts from of 21 districtsin Kampar Region. A purposive samplingtechnique was used for selecting the locations. The selected districts are predominantly rice production areas using semi irrigation or rain-fed system. The interviews with involving farmers, government extension staff and machinery suppliers (dealers) were conducted in 2015. The primary data were collected using structured questionnaires. Data collected include paddy field areas, rice production and yield, and type and number of farm machines. Secondary data were obtained from the records of the local government such as statistical bureau, food crop and fishery services, and district offices. Data collected were analyzed using descriptive statistics that were employed with mean and percentage.

\section{Results and Discussion}

\section{Rice area and production}

Rice is not main crop in Kampar region. However, rice is an important crop because it is a staple food for most people. Rice is mostly grown on the technical irrigation farm and rain-fed low land with $1-2$ cropping systems in a year, depending on climate conditions. Figure 1 depicts that paddy field area could not cultivated completely every year due to shortage labor, farm machines, capital, and climate conditions. The largest cultivated area was in 2011 ha and then declined to the lowest area in 2015. Similarly, rice production fluctuated every year during a period of 2009-2015. The highest production occurred in 2012 to be 52,154 tons and the lowest one was 29,666 tons in 2014. However, the rice production fluctuates depending upon the climatic conditions. In 2014, El-Nino hit Indonesia, which caused drier conditions over the country and crop losses.
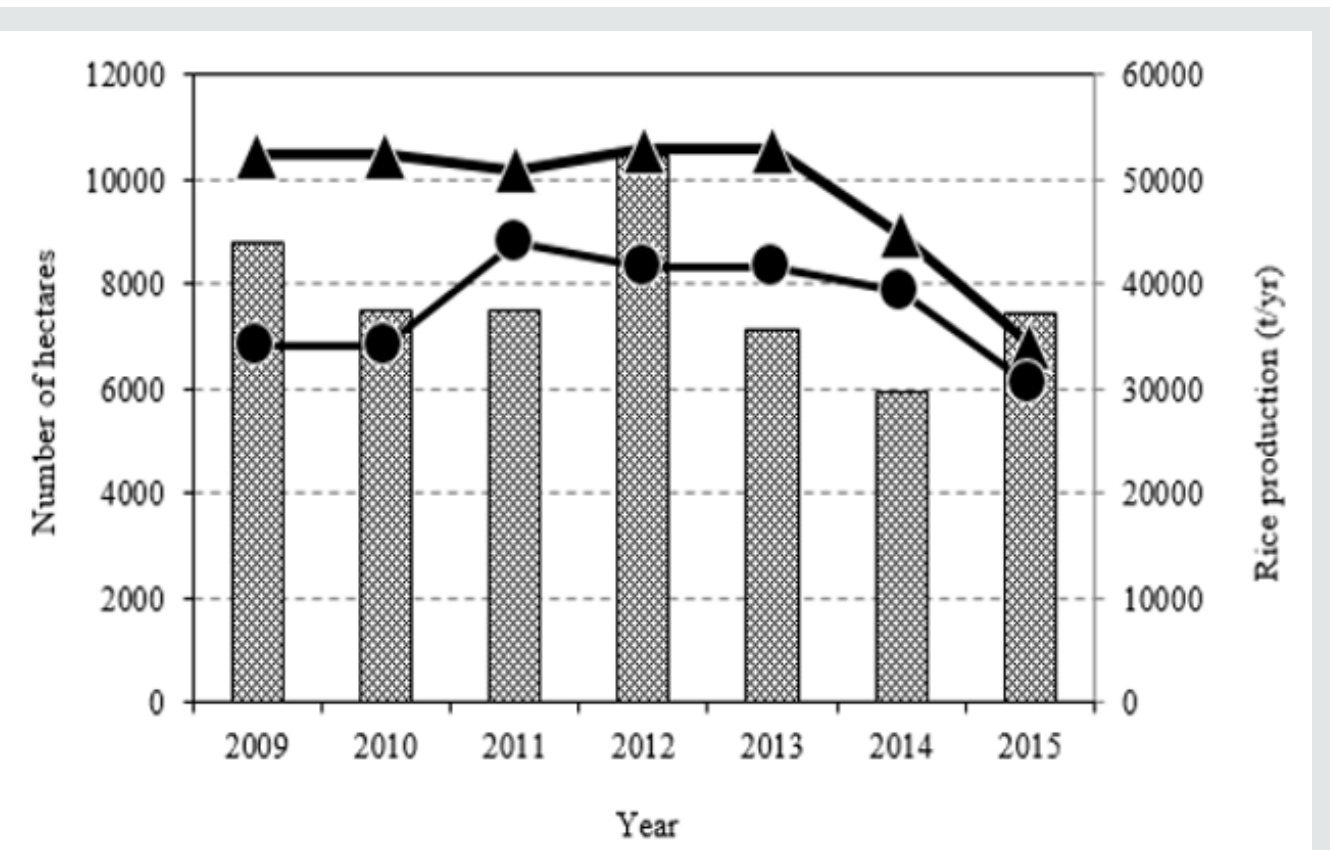

\section{Total rice production $\quad \longrightarrow$ Total paddy field area $\quad-\bullet-$ Culivated area}

Figure 1: Total paddy field area and production in Kampar Region during 2009-2015.

Source: Food Crop and Fishery Services [11]. 


\section{Farm machinery availability}

Rice farming in Kampar region is dominated by small-scale operations, so small type of farm machinery dominantly used by farmers for an economical operation. The use of farm machinery was to perform primarily power-intensive operations such as land preparation, irrigation, threshing, and milling. Therefore, types of farm machinery available on farm mostly include power tillers, water pumps, power threshers, and rice milling units (RMUs). Water pumps, for example, accounted to 254 units (38\%) in
2015, and followed by power tillers (29\%) and power threshers $(20 \%)$ in the same year. Meanwhile, both combine harvesters and reapers are still an introduction stage for rice farmers in the survey area. Development of the above types of farm machinery during a period of 2009-2015 is presented in Table 1 and Figure 2. Generally, the number of farm machines increased at about $15 \%$ annually. The highest growth was power threshers to about 55\% annually, followed by water pumps (23\%) and power tillers (13\%). Furthermore, RMUs increased by only $1 \%$ annually. This machine is used along year with different volume of work for each month [14].

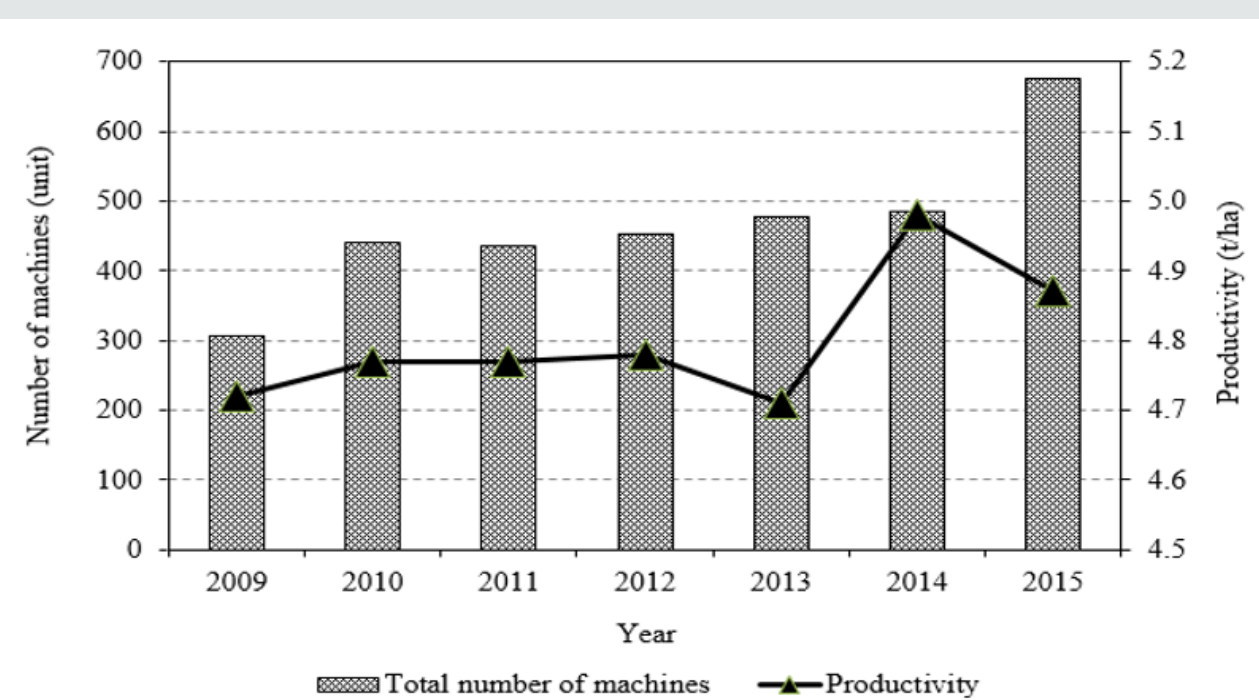

Figure 2: Total number of available machines and rice productivity during 2009-2015

Source: Food Crop and Fishery Services [11]

Table 1: Farm machinery development in Kampar region during 2009-2015.

\begin{tabular}{|c|c|c|c|c|c|c|c|}
\hline Machinery types & 2009 & 2010 & 2011 & 2012 & 2013 & 2014 & 2015 \\
\hline Large tractor & 0 & 0 & 0 & 5 & 4 & 8 & 8 \\
\hline Power tiller & 103 & 155 & 165 & 160 & 165 & 165 & 196 \\
\hline Water pump & 91 & 181 & 175 & 190 & 211 & 211 & 254 \\
\hline Power thresher & 22 & 35 & 27 & 37 & 37 & 37 & 133 \\
\hline Rice Milling Unit & 88 & 69 & 69 & 61 & 61 & 64 & 81 \\
\hline Combine harvester & 0 & 0 & 0 & 0 & 0 & 0 & 2 \\
\hline Reaper & 0 & 0 & 0 & 0 & 0 & 1 & 1 \\
\hline Total & 307 & 440 & 436 & 453 & 478 & 486 & 675 \\
\hline
\end{tabular}

Source: Food Crop and Fishery Services [11].

Figure 2 shows the development of farm machinery and rice productivity (crop yield) during 2009-2015. The total number of farm machines increased from 307 units in 2009 to 675 units in 2015 with an annual increase of $15 \%$. The increased number of farm machines did not show a significant effect on increasing rice productivity during the period. Although the number of farm machines increased significantly during the period, the rice productivity increased at a low rate during the same period and even declined to be the lowest rate of $0.5 \%$ annually in 2013. Moreover, when the number of farm machines increased at the highest rate in
2015 , the rice productivity showed to decrease, and it was lower than 2014. These conditions may be due to still an inadequate number of farm machines in the region. Increasing supply of farm machines is needed to achieve an adequate number of farm machines and then make a significant effect on rice productivity.

Farm machinery used by small farmers in Kampar Region is generally owned by individual farmer and farmer group. According to Figure 3, the individual owned was dominant in the Kampar region and their machines were purchased by 
themselves from dealers. The farm machinery which was owned by a farmer group came from direct government aid through the mechanization development program. The farm machines bought by the government were distributed to farmer groups to be used for custom hiring, especially for servicing group members [15]. The farm machines managed by individual farmers were bought itself and the excess capacity was provided to other farmers for providing the farm machinery hire services. The service charge differed between group farmers and individual farmers, and the group farmers offered lower rates compared to individual farmers. The machinery hire services are an alternative use to economically adjust ownership of the machines and obtain an additional income from the services. This machine hire business was reported to be profitable under individual management [16] as well as farmer group management [10].

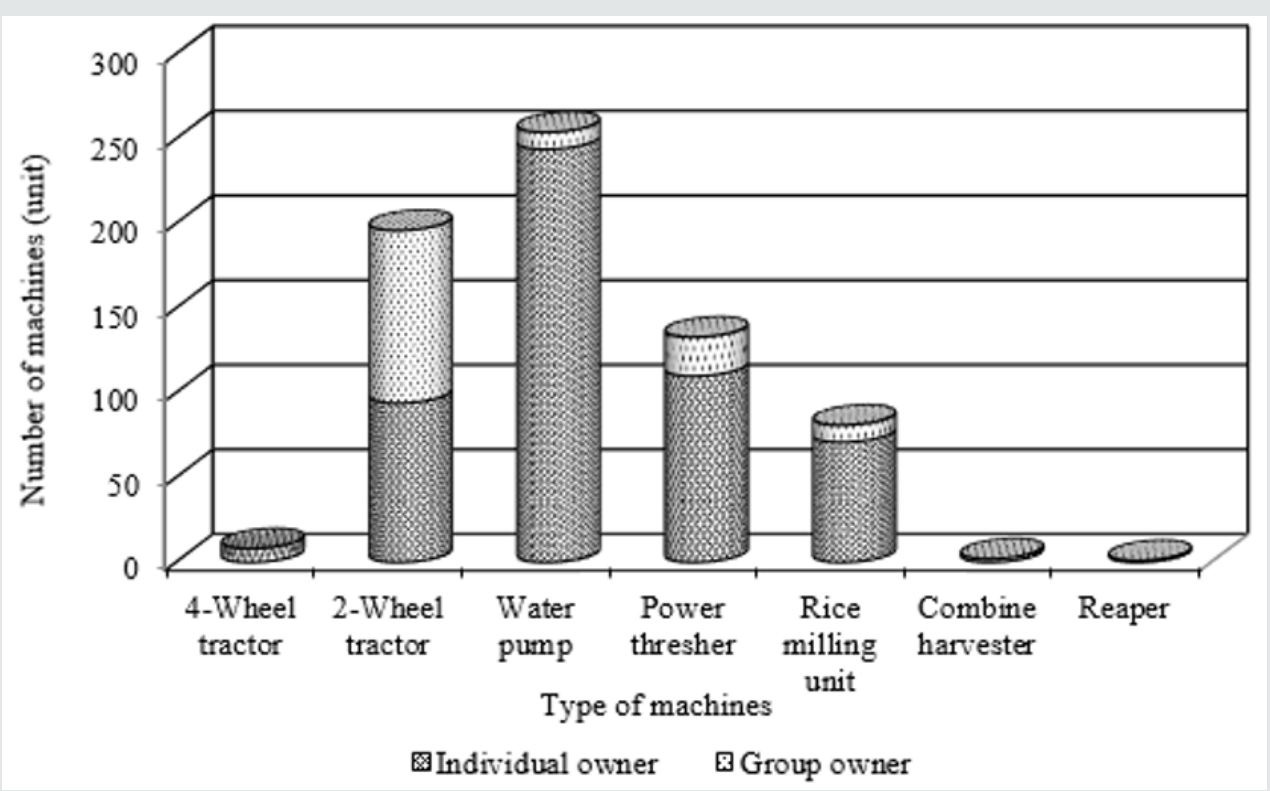

Figure 3: Farm machinery ownership system in Kampar region.

Source: Food Crop and Fishery Services [11]

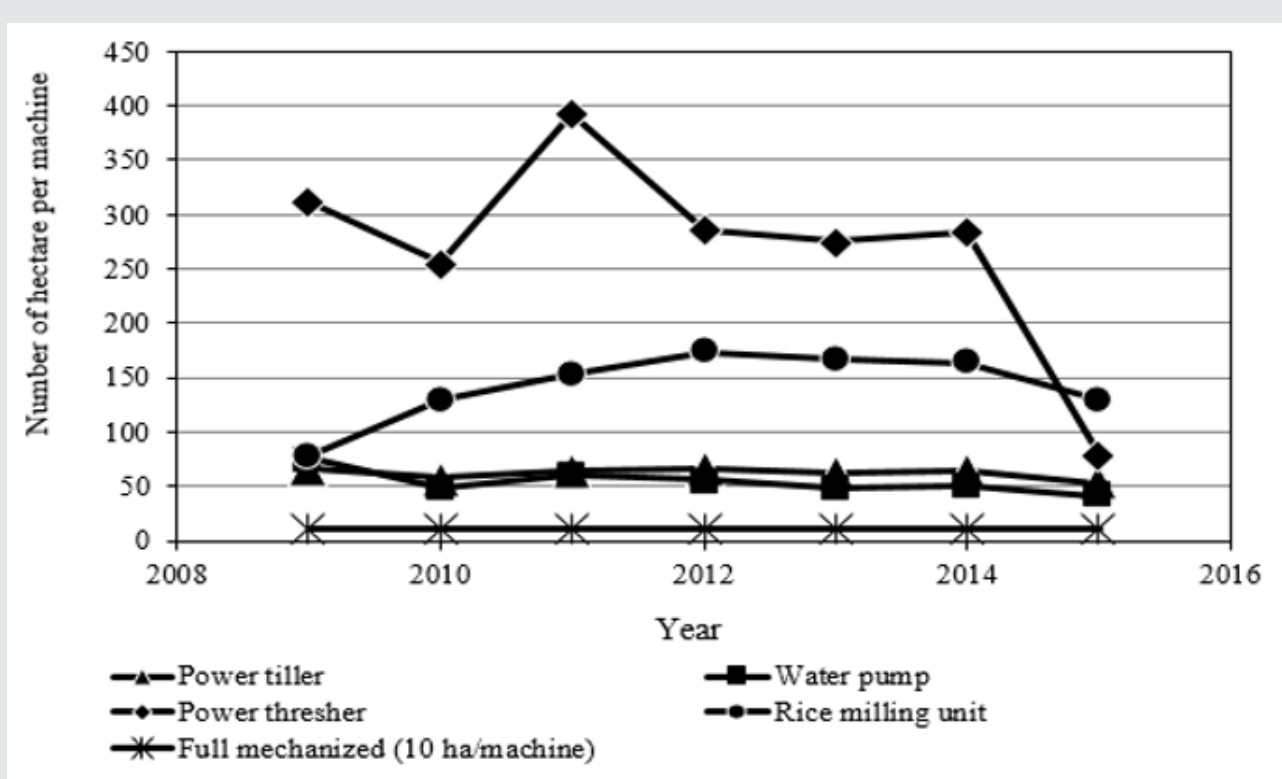

Figure 4: Density of farm machines during 2009-2015.

As outlined above, the number of available farm machines is still inadequate to make a significant increase of rice productivity in Kampar region. Figure 4 shows development number of hectares per machine in the region during 2009-2015. During the period, power threshers and rice milling units show the lowest number of hectares per machine. However, the density of both machines increased in 2015 due to increase number of the farm machinery on the farm. Consequently, the number of hectares per machines became to be 129 and 41 for power threshers and rice milling units, respectively. It means that the density of farm machinery increased 
according to increase the number of available machines. While, both power tillers and water pumps did not show significantly to increase machine density during the period. Generally, the density of the farm machinery has not been enough to achieve full mechanized for rice farm operations. Herdt [17] stated that to achieve full mechanization stage, for example, it requires about 100 power tillers per 1000 hectares (or 10 ha per power tiller). The result showed that the number of available power tillers in Kampar region was no sufficient to achieve full mechanization stage.

\section{Farm power availability}

The available power in the region is expressed as a number of horsepower per hectare (hp.ha-1). Farm power availability is directly related to the amount of power needed to perform farm operations. The availability of machine power during a period of 2009-2015 in Kampar region is presented in Figure 5. The total number of machine powers in the region increased from 1,566 hp $(1,168$ $\mathrm{kW})$ to $6,356 \mathrm{hp}(4,740 \mathrm{~W})$ with an increasing rate of about $29 \%$ annually. This power sourced from large/medium tractors, power tillers, water pumps, power threshers, rice milling units, combines, and reapers. The water pump had the largest contribution to the power, followed by power tillers and rice milling units. The number of the available power depends strongly on the number of farm machines. Based on the total power availability, available power per hectare also increased from $0.23 \mathrm{hp} \cdot \mathrm{ha}^{-1}\left(0.17 \mathrm{~kW} \cdot \mathrm{ha}^{-1}\right)$ to 0.61 hp.ha-1 (0.45 kW.ha-1) with an increasing rate of $21 \%$ annually. This number is not sufficient to make optimum rice yield which required at least 0.8 hp.ha-1 ${ }^{-12]}$. Comparing with Iran, for example, the available power has reached at the level of $0.86 \mathrm{~kW} \cdot \mathrm{ha}^{-1}{ }^{1}[18]$. The result suggests that the number of farm machines must be increased to meet power requirement for rice farm operations.

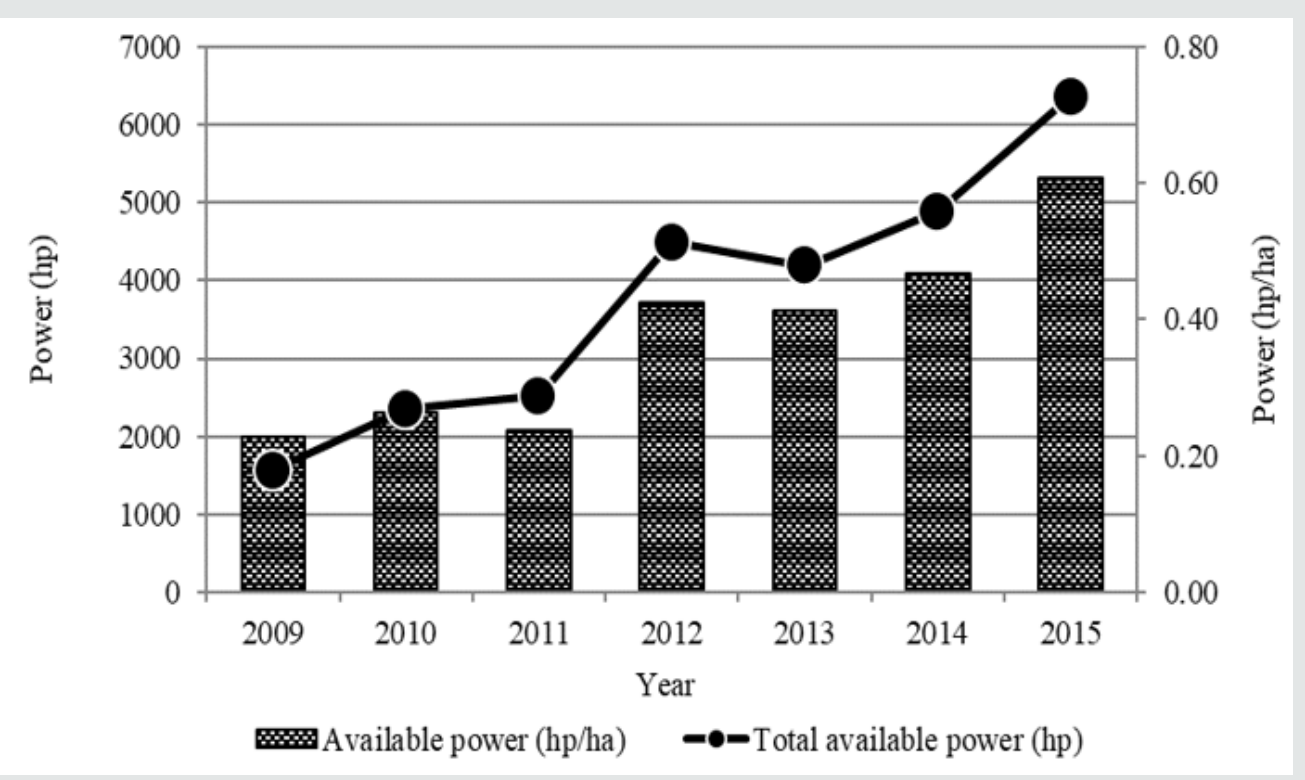

Figure 5: Number of available powers on farm during 2009-2015.

\section{Conclusion}

The number of farm machinery on farm is inadequate to provide a sufficient power for rice farm operations in Kampar region. Consequently, human power still remains as an important source of farm power in many areas in across the region. The increasing number of farm machines has no significant effect on rice productivity. Nevertheless, the insufficiency of available farm machines did not create demand of the machines. Furthermore, the shortage of farm machines affected the availability of power per hectare. The available machine power is still under the power requirement for achieving a maximum rice yield. However, the number of farm machines must meet the needs of small rice farmers. Therefore, government support is still required to the advancement of farm machinery in Kampar region.

\section{References}

1. Verma M, Tripathi A (2016) Perspective of the Status of Agricultural Mechanization in the Bihar State. International Journal of Emerging Technology \& Research 3(3): 10-17.

2. Mehta CR, Chandel NS, Senthilkumar T (2014) Status, Challenges and Strategies for Farm Mechanization in India. Agricultural Mechanization in Asia, Africa, and Latin America 45(4): 45-50.

3. Iqbal MA, Iqbal A, Afzal S, Akbar N, Abbas RN, Khan HZ (2015) In Pakistan, Agricultural Mechanization Status and Future Prospects. American-Eurasian Journal Agricultural \& Environment Sciences 15(1): 122-128.

4. Diao X, Silver J, Takeshima H (2016) Agricultural Mechanization and Agricultural Transformation. International Food Policy Research Institute (IFPRI), Washington, DC, USA.

5. Khambalkar V, Pohare J, Katkhede S, Bunde D, Dahatonde S (2010) Energy and Economic Evaluation of Farm Operations in Crop Production. Journal of Agricultural Science 2(4): 191-200. 
6. Jacobs CO, Harrell WR (1983) Agricultural Power and Machinery McGraw-Hill, Inc. New York, USA.

7. Binswanger H (1986) Agricultural Mechanization: A Comparative Historical Perspective. Research Observer 1(1): 27-56.

8. Hendriadi, A (2009) Country Report of Indonesia. Ministry of Agriculture. Republic of Indonesia. Jakarta.

9. Handaka (2005) Agricultural Engineering Research and Development in Indonesia: Challenge and Prospect toward Sustainable Agriculture and APCAEM program. Paper presented in APCAEM TC/GT Meeting in New Delhi, India 21-24.

10. Paman U, Inaba S, Uchida S (2016) Economic Aspects of Machinery Hire Services Managed by Farmer Groups in Kampar Regency, Indonesia. Applied Engineering in Agriculture 32(2): 169-179.

11. Food Crop and Fishery Services (2014) Serial Data of Food and Horticulture in 2013. Pekanbaru, Indonesia.

12. Jain BKS (1979) Tractors in Indian Agriculture - Their Place and Problem. Agricultural Mechanization in Asia, Africa, and Latin America, Autumn Issue 31-34.

13. Himanshu SK, Kumar S, Kumar A, Gupta KK (2012) Energy Economics Assessment of Crops in Traditional and Mechanized Farming. International Research Journal of Environment Sciences 1(5): 27-34.
14. Paman U, Bahri S, Asrol Liana L (2016) Distribution and Use Patterns of Small-Scale Rice Mills in Kampar Regency, Riau Province, Indonesia. International Journal of Advanced Science Engineering Information Technology 6(2): 149-152.

15. Paman U, Inaba S, Uchida S (2014) Farm Machinery Hire Services for Small Farms in Kampar Regency, Riau Province, Indonesia. Applied Engineering in Agriculture 30(5): 699-705.

16. Paman U, Uchida S, Inaba S (2010) Economic Potential of Tractor Hire Business in Riau Province, Indonesia: A Case Study of Small Tractors for Small Rice Farms. Agricultural Engineering International: CIGR Journal 12(1): 135-142.

17. Herdt RW (1983) Mechanization of Rice Production in Developing Asian Countries: Perspective, Evidence, and Issues. In Consequences of Small-Farm Mechanization; International Rice Research Institute and Agricultural Development Council, Los Banos, Philippines P. 1-13.

18. Ghadiryanfar M, Keyhani A, Akram A, Rafiee S (2009) A Pattern for Power Distribution Based on Tractor Demand in Iran. Agricultural Engineering International: The CIGR Journal of Scientific Research and Development 11: 1-9.

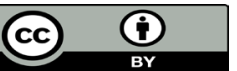

This work is licensed under Creative Commons Attribution 4.0 License

To Submit Your Article Click Here: Submit Article

DOI: $10.32474 / C I A C R .2020 .08 .000282$

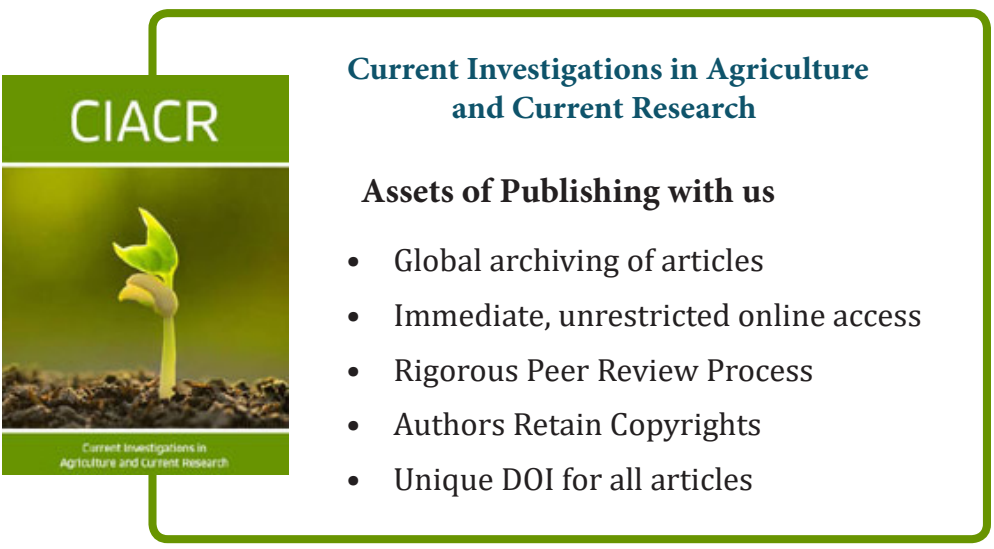

